\title{
Influence of temperature, salinity and $E$. coli tissue content on immune gene expression in mussel: Results from a 2005-2008 survey
}

\author{
Hui Li ${ }^{\mathrm{a}, 1}$, Mylène Toubiana ${ }^{\mathrm{a}}$, Patrick Monfort ${ }^{\mathrm{a}}$ and Philippe Roch ${ }^{\mathrm{a}, ~ *}$
}

\author{
a Ecosystèmes Lagunaires, JRU CNRS-IFREMER-Université Montpellier 2, cc093, place E. Bataillon, F-34095 \\ Montpellier cedex 05, France \\ ${ }^{1}$ Present address: College of Life Sciences, Shenzhen University, Shenzhen 518060, People's Republic of \\ China.
}

*: Corresponding author : P. Roch, Tel.: +33 4671447 12; fax: +33 4671446 73, email address : proch@univ-montp2.fr

\begin{abstract}
:
Several bivalves, including mussels, suffered from mortalities particularly in summer. To look for the possible effect of environmental parameters on immune capacities, Mytilus galloprovincialis were collected monthly from August 2005 to July 2008 from the Palavas Laguna, French Mediterranean coast. Q-PCR was used to quantify the expression of three antimicrobial peptide genes (defensin, mytilin $B$ and myticin B), in addition to lysozyme and HSP70. House keeping gene was 28S rRNA. Defensin, myticin $B$ and lysozyme appeared more expressed in spring-summer than in winter. In contrast, HSP70 expression was higher in winter. Statistical studies using principal component analysis (PCA) and multiple regression models revealed positive influence of temperature on 285 $r R N A$, defensin, myticin B and lysozyme expressions, but not on mytilin B and HSP70. The positive influence was significant for defensin and lysozyme expression, but relationships cannot be quantified. Similarly, salinity appeared to influence defensin expression, but this relationship cannot be quantified neither. E. coli tissue content appeared without influence. Consequently, there was no clear relationship between environmental parameters and immune-related gene expressions, demonstrating anti-infectious capabilities cannot be evaluated using only the expression of such genes as markers.
\end{abstract}

Keywords: Antimicrobial peptide; Defensin; Mytilin; Myticin; Lysozyme; HSP70; Q-PCR; Immune survey; Seasonal variations; Innate immunity; Mytilus; Mollusks 


\section{Introduction}

Effects of environmental parameters on immune functions of mussels have been extensively studied due to the sentinel role of such mollusk and numerous reports considered the effects of xenobiotics [1-4], but few considered bacteria [5-7] and none the in situ seawater micro fauna. Physical and biological parameters of the environment where the mussels live are largely dependent on the season and fluctuations of numerous criteria were reported in mussels as related to seasons : enzyme activities [8], circulating hemocyte number [9], protein content of hemolymph, lysozyme and agglutinin activities [10], antibacterial response induced by LPS [11], lipid composition [12], cytolytic activity [13] and nitric oxide production [14], for instance. Also mortalities were frequently reported in relationships with the season, to such extend that they were called summer mortalities, not only in mussels [15, 16] but also in oysters [17-19]. Concerning immunity, we previously demonstrated in Northern blot that the expression of AMP genes, defensin, mytilin $B$ and myticin $B$ were constitutively expressed in winter, whereas expression only mytilin and myticin $B$ were detectable also in summer [20]. In addition, expression of both defensin and mytilin $B$ were decreased following bacterial injection in winter, heat-shock resulting in no change in mytilin $B$ expression but in suppression of defensin expression in winter and its induction in summer.

Here, we evaluated by Q-PCR the expression of several immune-related genes (defensin, mytilin B, myticin B and lysozyme) and of HSP70 in mussels collected once a month at the same location during three consecutive years. Some environmental parameters (seawater temperature and salinity) and E. coli content of mussel tissues were joined to look for possible correlation with expression of such genes.

\section{Material and methods}

60

\subsection{Mussels, hemolymph and hemocyte sampling}

Adult mussels, Mytilus galloprovincialis (6-7 cm shell length), were purchased every 4 weeks from August 2005 to July 2008, from the marine farm Les Compagnons de Maguelone located in the Prévost Laguna of Palavas (French Mediterranean coast). They were acclimated for $24 \mathrm{~h}$ in the laboratory (15 mussels in 251 of sea water per aquarium) in a flow-through air system before hemolymph collection.

Hemolymph ( $0.8 \mathrm{ml}$ per mussel) was collected from the posterior adductor muscle with a $1 \mathrm{ml}$ disposable syringe containing $0.2 \mathrm{ml}$ of anti-coagulant modified Alsever's solution $(27 \mathrm{mM}$ sodium citrate, $115 \mathrm{mM}$ glucose, $336 \mathrm{mM} \mathrm{NaCl}, 18 \mathrm{mM}$ EDTA, pH 7.0). Hemolymphs from 10 
resuspended in $1 \mathrm{ml}$ Trizol Reagent (Invitrogen) and stored at $-20^{\circ} \mathrm{C}$ until used. Four pools of 10 mussels each, as replicates, were used for each sampling month. The full survey involved 1,440 mussels.

\section{2. cDNA synthesis and quantitative PCR (Q-PCR)}

Total RNA was extracted according to manufacturer's instructions and resuspended in 45 $\mu \mathrm{l}$ of Tris-EDTA buffer (TE: $10 \mathrm{mM}$ Tris-HCl, pH 8.0, 1 mM EDTA). RNA concentrations were measured and quality controlled on spectrophotometer ND-1000 (NanoDrop Technologies). First strand cDNAs were synthesized on $5 \mu \mathrm{g}$ of total RNA using hexaprimers (Invitrogen) and murine leukemia virus reverse transcriptase (Promega), purified through QIAquick Column (Qiagen) then kept in nuclease-free water at $-20^{\circ} \mathrm{C}$ until use.

Q-PCR was performed using the SYBR Green chemistry on a LightCycler 480384 wellplate (Roche). Primer sequences and specificity controls were previously reported [21, 22]. QPCR mixture contained the following: $1 \mu \mathrm{l}$ first strand cDNA (10 ng), $0.75 \mu 1$ of each specific primers at a concentration of $25 \mu \mathrm{M}, 2.5 \mu \mathrm{l}$ of mix (Roche) containing FastStart Taq DNA polymerase, reaction buffer $2 \mathrm{x}$, dNTP mix, SYBR Green 1 dye and $\mathrm{MgCl}_{2}$. The PCR programme started with initial Taq polymerase activation at $95^{\circ} \mathrm{C}$ for $10 \mathrm{~min}$, followed by 40 cycles at $95^{\circ} \mathrm{C}$ for $10 \mathrm{sec}, 65^{\circ} \mathrm{C}$ for $10 \mathrm{sec}$ and $72^{\circ} \mathrm{C}$ for $15 \mathrm{sec}$. Melting temperatures were measured by returning to $65^{\circ} \mathrm{C}$ for $30 \mathrm{sec}$ and gradual heating to $95^{\circ} \mathrm{C}$. Negative control reactions contained water in place of cDNA template and were included in each run to ensure the absence of contamination. Calibration curves were obtained using 10-fold serial dilutions of the corresponding amplicon in $10 \mu \mathrm{g} / \mathrm{ml}$ sonicated salmon sperm DNA (Sigma). House keeping gene was $28 S$ ribosomal DNA, as previously validated [23].

\subsection{Q-PCR data analysis}

Crossing point values expressed in cycle numbers were measured according to the threshold position of 4.2 and converted into equivalent target amount (ETA) by the LightCycler 480 built-in software (Roche) using statistical calibration curves. Expression level of gene of interest was calculated from the ratio of ETA for the considered gene on ETA for $28 S$ rDNA within the same sample. Data were presented as arithmetical mean of the four replicates measured in duplicate \pm SEM. Statistical significant differences between data were established by Student's $t$-test using t-Ease 2.8 ISI software. Differences were considered as significant for $\mathrm{p}<0.05$.

\subsection{Environmental parameters}


Seawater temperature (measured by electronic probe) and salinity (measured by in situ conductivity) values at the dates and unique location $\left(43^{\circ} 31^{\prime} 15 \mathrm{~N}-03^{\circ} 54^{\prime} 33 \mathrm{E}\right)$ where mussels

108 have been collected for gene expression measurements, came from the Ifremer's network Réseau de surveillance $d u$ phytoplancton et des phytotoxines (REPHY). E. coli tissue contents of mussels at the same location, quantified by colorimetric enumeration based on $\beta$-glucuronidase activity [24] were from Ifremer's network Réseau de contrôle microbiologique des zones de production de coquillages (REMI).

Data were uploaded from

113 http://www.ifremer.fr/envlit/surveillance, a website devoted to coastal environments.

\subsection{Statistics}

Statistics analysis were done with R software available at http://www.R-project.org, using ade4 package [25] and ade4TkGUI package [26].

2.5.1. Descriptive statistics: Principal component analysis (PCA) was used to describe data and to study the structures and correlations. Analysis was done on centred and scaled data.

2.5.2. Multiple regression models: To learn more about relationships between each gene expression and environmental data, we tried to define 6 multiple linear models on centred and scaled data. For each model, Fisher's method was used to look for global influence of environmental parameters (Ho: regression coefficients $=0$ ). Student's method was used to reveal significant influence of each environmental parameter on expression (Ho: regression coefficient of each parameter $=0$ ). In the situation of non nullity of one or several coefficients, normality of residuals of the model has been tested for validation using the Shapiro-Wilk's method.

\section{Results}

\subsection{Expression of $28 \mathrm{~S}$ rDNA}

The intensity of expression of $28 S$ rDNA was subjected to variations according to the month of collection. Lowest expressions were recorded from Aug 05 to Jan 06 (Fig. 1) with statistically significant difference between Oct 05 and Oct $06(\mathrm{p}=0.0002)$ for instance, but not between Oct 06 and Oct 07 ( $\mathrm{p}=0.51)$. Similarly, statistically significant difference was observed between Feb 06 and Feb 07 (p=0.035), but not between Feb 07 and Feb 08 ( p=0.087). Lower expressions were consistent during Apr-Aug 07, i.e. during spring-summer times, with expression statistically significantly lower in Jun 07 than in Jun $06(p=0.00016)$, but not than in Jun 08 ( $\mathrm{p}=0.96$ ). In addition, no difference in expression was observed between Sep 07 and Jul 08. 


\subsection{Expression of AMPs and lysozyme}

Global observation on Figure 2 was on variations of expressions. Evident is that defensin expression was higher in summer, with a maximum in Sep 05, Aug 06 and Aug 07, statistically significantly different between May and Aug $06(\mathrm{p}=0.0028)$, for instance. Such highest expressions ranged from 0.45 ETA (Sep 05) to 0.75 ETA (Aug 06) and 2.07 ETA (Aug 07), i.e. 4.6-folds the expression measured in Sep 05. Particularly low expression of defensin was in winter, close to the detection sensitivity of the Q-PCR technology used, with no statistically significant difference between the minimum values recorded from Jan 06 (0.01 ETA), Jan 07 (0.03 ETA) and Jan 08 (0.02 ETA).

Mytilin $B$ expression did not seem to be regulated by the season, except during the winter 05, with the highest recorded values of 30.68 ETA (Dec 05) and 22.27 ETA (Jan 06). Such increased expression was not observed during the winters 06 and 07 ( $p=0.0040$ between Dec 05 and Dec 06). Minimum expressions were from Apr 06 (0.85 ETA) to Apr 07 (0.86 ETA) with no statistically significantly difference. Similarly, no statistically significantly difference in mytilin $B$ expression were recorded from May 07 (0.57 ETA) to Jul 08 (0.71 ETA), i.e. during 15 consecutive months, with $\mathrm{p}=0.41$ between Dec 07 and May 08, for instance. Meanwhile, expression in Dec 07 was 2.2-fold ( $\mathrm{p}=0.0019)$ higher from expression in Dec 06.

Lower expression of myticin B was recorded during the winter times (Nov 05 and Jan 06, Dec 06 and Feb 07, Nov 07 and Jan 08), with no significant difference between Jan 06 (19.42 ETA) and Feb 07 (14.28 ETA, p=0.23) or between Feb 07 and Jan 08 (34.26 ETA, p=0.09). Higher expressions were recorded during Dec 05 (151.67 ETA), Apr 06 (127.49 ETA), Oct 07 (124.24 ETA) and more consistent between Feb 08 (133.35 ETA) and Jul 08 (250.42 ETA).

Lysozyme underwent clear seasonal variations of expression with maximum in Oct 05, Apr-Aug 06, May 07, Jul-Aug 07, Oct 07 and Apr-Jul 08, with no significant differences between the years, with $\mathrm{p}=0.41$ between May 06 (10.17 ETA) and May 07 (7.78 ETA), and p=0.54 between May 07 and May 08 (9.56 ETA). Such higher expressions were statistically different from expressions in winter 06: p=0.004 between May 06 and Feb 06 (3.00 ETA), winter 07: $\mathrm{p}=0.029$ between May 07 and Feb 07 (1.33 ETA), and winter 08: $\mathrm{p}=0.021$ between May 08 and Mar 08 (4.38 ETA), for instance. Exception was for Oct 05 with the highest lysozyme expression recorded: 15.18 ETA.

\subsection{Expression of $\mathrm{HSP} 70$}

Higher values for HSP70 expression were measured in Dec 05 (31.80 ETA), Jan 06 (30.88 ETA), Aug 07 (25.24 ETA), Dec 07 (22.34 ETA) and Jul 08 (26.38 ETA), with statistically significantly difference with low expression generally recorded in summer (Fig. 2). 
In addition to Aug 05 (6.51 ETA), low expressions were recorded constantly from Feb 06 (8.39 ETA) to Apr 07 (5.04 ETA).

\subsection{Environmental parameters}

Seawater temperature measured the day of mussel collection underwent expected variations ranged from $9.2^{\circ} \mathrm{C}$ (Jan 06) to $23^{\circ} \mathrm{C}$ (Jul 07) with normal Mediterranean seasonal rhythm (Fig. 2, upper panel). Salinity was simultaneously measured, revealing 4 low salinity periods corresponding to heavy rainfalls in Sep 05 (24.2 g/l), Sep-Dec 06 (about $30 \mathrm{~g} / \mathrm{l}$ ), May 07 $(27.5 \mathrm{~g} / \mathrm{l})$ and Jun $08(21.3 \mathrm{~g} / \mathrm{l})$. The number of E. coli measured in $100 \mathrm{~g}$ of mussel tissues was remarkably low (130-250 bacteria) and constant during summer 06 and the full year 07 until Jun 08, i.e. during 17 consecutive months. Four abnormally elevated contents were recorded in SepNov 05 (7,100-3,200 bacteria), Feb 06 (4,100 bacteria), Nov 06 (4,500 bacteria) and Jun 08 (8,600 bacteria).

\subsection{Correlations between gene expressions and environmental parameters}

3.5.1. Descriptive statistics. Six PCA have been performed to represent each gene expression according to salinity, temperature and E. coli tissue content. In each case, only the representation of variables on the main plan constructed by factorial axis 1 and 2, has been analyzed because representing 70-80 \% of total inertia. On the first axe and for all analysis, negative correlation has been observed between salinity and $E$. coli tissue content. On the second axe, correlation existed between the expression of each gene and the temperature, with the exception of HSP70. The correlation was positive for $28 S$ rDNA, defensin, myticin and lysozyme expression and negative for mytilin expression (Fig. 3).

3.5.2. Multiple regression models. Fisher's test for each model concerning global nullity of coefficients was significant ( $\mathrm{p}<0.05$, Ho rejected) only for defensin and lysozyme expression, revealing significant influence of environmental parameters on the expression of these 2 genes.

- Defensin model: Student's test was significant $(\mathrm{p}<0.05$, Ho rejected) revealing significant influence of temperature and salinity on defensin expression. Meanwhile, these relationships cannot be quantified because normality of residuals was rejected $(\mathrm{p}<0.05)$ and the model could not be validated.

- Lysozyme model: Student's test was significant $(\mathrm{p}<0.05$, Ho rejected) revealing significant influence of temperature on lysozyme expression. Meanwhile, as for defensin model, this relationship cannot be quantified because normality of residuals was rejected $(\mathrm{p}<0.05)$ and the model could not be validated. 


\section{Discussion}

The main criterion to decide for a house keeping gene is its constant expression all along the experiment. In previous reports, we found $28 S$ rDNA a suitable house keeping gene to study the variations of several immune-related genes following various treatments [21, 22]. Such treatments were not statistically significantly affecting the expression of $28 S$ rDNA. During the course of the present multi annual survey, we also focused on $28 S$ rDNA for Q-PCR calculations. It was obvious that $28 S \mathrm{rDNA}$ expression was not constant all along the year, but followed some rhythms, with lower expression Aug 05-Jan 06 and Apr 07-Aug 07, and higher expression Jun 06-Mar 07. One can speculate that such differences in expression must be related to the level of mussel metabolism which is known to fluctuate according to season [27] and reproduction [28].

The calculation mode based on the ratio of ETA for the considered gene on ETA for $28 \mathrm{~S}$ rDNA, compensated the variations in the house keeping gene expression. Defensin expressed in summer, from Apr to Oct, and was nearly undetectable in winter, from Dec to Mar, which is contradictory to our previous observations done in Northern [7]. Mytilin B expression appeared constant with a low level from Apr 06 to Apr 07 and slightly higher values from May 07 to Jul 08. Exception was during winter 05 with significantly up-regulation of mytilin $B$ expression. Highest expression of myticin B and lysozyme occurred in summer whereas HSP7O expression appeared more erratic with maxima in Dec 05, Aug 07, Dec 07 and Jul 08. Consequently, the five genes behave differently according to the season, but they all underwent almost a year of low expression, starting Feb-May 06, particularly obvious for mytilin B and HSP70. We must notice the deviant comportments during the winter 05-06 with the highest expression of mytilin B, lysozyme and HSP70, the expression of the later being reported as showing significant correlation with the seawater temperature [29].

Highest E. coli tissue content of mussel tissues, reflecting human faecal contamination not correctly eliminated by public sewage systems, were observed at the time of lowest salinity corresponding to heavy rainfalls during Sep-Nov 05, Nov 06 and Jun 08. Meanwhile, other low salinity values (Apr 06, Sep 06 and May 07) were not associated with high E. coli tissue content. Reciprocally, high E. coli tissue content measured in Feb 06 was not related to low salinity, suggesting either not a strict relationship between the 2 phenomena or, most probably, a rapid clearance of E. coli from the mussel tissues, as we observed for Vibrio splendidus, $V$. anguillarum and Micrococcus lysodeikticus [30]. No particular relationship has been observed between $E$. coli tissue content and seawater temperature, obviously more elevated in summer, with a maximum of $23^{\circ} \mathrm{C}$, than in winter, with a minimum of $8.5^{\circ} \mathrm{C}$. When compared to the 
observed in summer cannot be correlated to the reaction against more numerous bacteria. Moreover, the two highest E. coli tissue content observed in Feb 06 and in Nov 06 corresponded to the lowest expressions of defensin, myticin $B$ and lysozyme, rejecting the hypothesis of correlation between expression of these immune gene and the presence of bacteria. Highest concentration of $E$. coli tissue content in Jun 08, not correlated to particularly high immune gene expression, confirmed the above assertion. Meanwhile, both lysozyme and mytilin B were upregulated at the end of 2005 at the time salinity was increasing and E. coli tissue content elevated, but decreasing. But such relationships were less obvious in Jun 08, and not confirmed at the end of 2006. Statistical studies with PCA and multiple regression models revealed positive influence of temperature on $28 S$ rDNA, defensin, myticin B and lysozyme expressions, but negative influence on mytilin $B$ expression. The positive influence was significant for defensin and lysozyme expression, but relationships cannot be quantified. Similarly, salinity appeared to influence defensin expression, but this relationship cannot be quantified neither.

General observations in M. galloprovincialis were on the highest concentrations/activities during summer times, with correlations to highest water temperature: hemolymph protein concentration, lysozyme and agglutinin activities [10], total hemocyte count (THC) [9], NO production [14], and HSP70 and multi xenobiotic resistance (MXR) protein accumulations [31], for instance. However, intensity of cytolytic activity correlated to water temperature, but experiments in aquaria demonstrated this parameter is not the main cause of the fluctuation [13]. Also in M. edulis, activities such are glutathione (GSH), GHS-peroxidase and catalase were the highest in summer [8]. Other observations in M. galloprovincialis were on higher prevalence of gonad neoplasm between Apr and Jun [32] and on higher percentage of inflammatory lesions caused by parasites in summer than in winter [27], exactly as reported for the Japanese pearl oyster, Pinctada fucata, infected by the marine birnavirus (MABV) [33]. In contrast, greater concentrations of HSP7O in winter in the horse mussel, Modiolus modiolus, suggested adjustment of such chaperone functions to cold temperature $\left(5^{\circ}\right.$ versus $\left.15^{\circ} \mathrm{C}\right)$ [34]. Correlation between maxima seawater temperatures and occurrence of mortalities was proposed concerning the European abalone, Haliotis tuberculata (Mollusk, Gastropod) [35] due to emerging vibriosis [36]. In addition, diseases are known to be linked to reproductive cycle because reproduction is a stressful event using energy that would otherwise be available for other functions. Such relationships between spawning and mortality have been reported in oyster [37], mussels [28], abalone [38] and Manila clam Ruditapes philippinarum [39]. One can expect the immune gene expressions to be down-regulated during gonad maturation, lasting until spawning. In the present report, up-regulation of mytilin $B$ and $H S P 70$ was observed during the first reproductive period 
during the following years. Consequently, relationships between environmental parameters and immune-related gene expression appeared not simple, demonstrating anti-infectious capabilities cannot be evaluated using only such genes as markers.

In conclusion, different levels of expression have been observed for several immune genes along the 3-years survey, with some seasonal variability. Statistical studies revealed positive influence of temperature on $28 S$ rDNA, defensin, myticin B and lysozyme expressions, but not on mytilin B and HSP70. Salinity positively influenced defensin expression only, whereas E. coli tissue content appeared without influence.

\section{Acknowledgements}

HL and MT were fully supported by the EU programme Imaquanim (FOOD-CT-2005007103). Data from REMI and REPHY networks were collected with the help of Isabelle Amouroux and Catherine Belin from Ifremer-Nantes (France).

\section{References}

[1] Pipe RK, Coles JA. Environmental contaminants influencing immune function in marine bivalve molluscs. Fish Shellfish Immunol 1995;5:581-95.

[2] Dyrynda EA, Pipe RK, Burt G, Ratcliffe N. Modulations in the immune defences of mussels (Mytilus edulis) from contaminated sites in the UK. Aquat Toxicol 1998;42:16985.

[3] Canesi L, Ciacci C, Betti M, Scarpato A, Citterio B, Pruzzo C, et al. Effects of PCB congeners on the immune function of Mytilus hemocytes: alterations of tyrosine kinasemediated cell signaling. Aquat Toxicol 2003;63:293-306.

[4] Auffret M, Rousseau S, Boutet I, Tanguy A, Baron J, Moraga D, et al. A multiparametric approach for monitoring immunotoxic responses in mussels from contaminated sites in Western Mediterranea. Ecotoxicol Environ Saf 2006;63:393-405.

[5] Pruzzo C, Gallo G, Canesi L. Persistence of vibrios in marine bivalves: the role of interactions with hemolymph components. Environ Microbiol 2005;7:761-72.

[6] Ordas M, Novoa B, Figueras A. Modulation of chemiluminescence response of Mediterranean mussel (Mytilus galloprovincialis) hemocytes. Fish Shellfish Immunol 2000;10:611-22.

[7] Mitta G, Hubert F, Dyrynda EA, Boudry P, Roch P. Mytilin B and MGD2, two antimicrobial peptides of marine mussels: gene structure and expression analysis. Dev Comp Immunol 2000;24:381-93.

[8] Sheehan D, Power A. Effects of seasonality on xenobiotic and antioxidant defence mechanisms of bivalve molluscs. Comp Biochem Physiol C Pharmacol Toxicol Endocrinol 1999;123:193-9.

[9] Carballal MJ, Villalba A, Lopez C. Seasonal variation and effects of age, food availability, size, gonadal development, and parasitism on the hemogram of Mytilus galloprovincialis. J Invertebr Pathol 1998;72:304-12. 
[10] Santarém MM, Robledo JAF, Figueras A. Seasonal changes in hemocytes and serum defense factors in the blue mussel Mytilus galloprovincialis. Dis Aquat Organ 1994;18:217-22.

[11] Hernroth B. The influence of temperature and dose on antibacterial peptide response against lipopolysaccharide in the blue mussel, Mytilus edulis. Fish Shellfish Immunol 2003;14:25-37.

[12] Saito H. Lipid and FA composition of the pearl oyster Pinctada fucata martensii: influence of season and maturation. Lipids 2004;39:997-1005.

[13] Malagoli D, Casarini L, Ottaviani E. Monitoring of the immune efficiency of Mytilus galloprovincialis in Adriatic Sea mussel farms in 2006: regular changes in cytotoxicity during the year. Invertebr Survey J 2007;4:10-2.

[14] Novas A, Barcia R, Ramos-Martinez JI. Nitric oxide production by haemocytes from Mytilus galloprovincialis shows seasonal variations. Fish Shellfish Immunol 2007;23:886-91.

[15] Tremblay R, Myrand B, Sevigny J-M, Blier P. Bioenergetic and genetic parameters in relation to susceptibility of blue mussel, Mytilus edulis (L.) to summer mortality. J Exp Mar Biol Ecol 1998;221:27-58.

[16] Myrand B, Gaudreault J. Summer mortality of blue mussels (Mytilus edulis L.) in the Magdalen Islands (southern Gulf of St. Lawrence, Canada). J Shellfish Res 1995;14:395404.

[17] Lacoste A, Jalabert F, Malham S, Cueff A, Gelebart F, Cordevant C, et al. A Vibrio splendidus strain is associated with summer mortality of juvenile oysters Crassostrea gigas in the Bay of Morlaix (North Brittany, France). Dis Aquat Organ 2001;46:139-45.

[18] Friedman CS, Estes RM, Stokes NA, Burge CA, Hargove JS, Barber BJ, et al. Herpes virus in juvenile Pacific oysters Crassostrea gigas from Tomales Bay, California, coincides with summer mortality episodes. Dis Aquat Organ 2005;63:33-41.

[19] Garnier M, Labreuche Y, Garcia C, Robert M, Nicolas JL. Evidence for the involvement of pathogenic bacteria in summer mortalities of the Pacific oyster Crassostrea gigas. Microb Ecol 2007;53:187-96.

[20] Roch P. Behaviour of defense peptides in environmentally stressed mussels. Revue Médicale Vétérinaire 2001;153:517-20.

[21] Cellura C, Toubiana M, Parrinello N, Roch P. Specific expression of antimicrobial peptide and HSP70 genes in response to heat-shock and several bacterial challenges in mussels. Fish Shellfish Immunol 2007;22:340-50.

[22] Li H, Parisi MG, Toubiana M, Cammarata M, Roch P. Lysozyme gene expression and hemocyte behaviour in the Mediterranean mussel, Mytilus galloprovincialis, after injection of various bacteria or temperature stresses. Fish Shellfish Immunol 2008;25:143-52.

[23] Cellura C, Toubiana M, Parrinello N, Roch P. HSP70 gene expression in Mytilus galloprovincialis hemocytes is triggered by moderate heat shock and Vibrio anguillarum, but not by V. splendidus or Micrococcus lysodeikticus. Dev Comp Immunol 2006;30:984-97.

[24] Adams MR, Grubb SM, Hamer A, Clifford MN. Colorimetric enumeration of Escherichia coli based on beta-glucuronidase activity. Appl Environ Microbiol 1990;56:2021-4.

[25] Dray S, Dufour AB. The ade4 package: implementing the duality diagram for ecologists. Journal of Statistical Software 2007;22:1-20.

[26] Thioulouse J, Dray S. ade4TkGUI: ade4 Tcl/Tk graphical user interface. R package version 0.2-3. http://pbiluniv-lyon1fr/ade4TkGUI 2008:Mailing list http://listes.univlyon1.fr/wws/info/adelist.

[27] Bodin N, Burgeot T, Stanisiere JY, Bocquene G, Menard D, Minier C, et al. Seasonal variations of a battery of biomarkers and physiological indices for the mussel Mytilus 
galloprovincialis transplanted into the northwest Mediterranean Sea. Comp Biochem Physiol C Toxicol Pharmacol 2004;138:411-27.

[28] Myrand B, Guderley H, Himmelman J. Reproduction and summer mortality of blue mussels Mytilus edulis in the Magdalen Islands, southern Gulf of St. Lawrence. Marine Ecology Progress Series 2000;197:193-207.

[29] Hamer B, Hamer DP, Muller WE, Batel R. Stress-70 proteins in marine mussel Mytilus galloprovincialis as biomarkers of environmental pollution: a field study. Environ Int 2004;30:873-82.

[30] Parisi MG, Li H, Jouvet LBP, Dyrynda EA, Parrinello N, Cammarata M, et al. Differential involvement of mussel hemocyte sub-populations in the clearance of bacteria. Fish Shellfish Immunol 2008.

[31] Minier C, Borghi VV, Moore MN, Porte C. Seasonal variation of MXR and stress proteins in the common mussel, Mytilus galloprovincialis. Aquat Toxicol 2000;50:16776.

[32] Alonso A, Suarez P, Alvarez C, San Juan F, Molist P. Structural study of a possible neoplasia detected in Mytilus galloprovincialis collected from the Ria of Vigo (NW Spain). Dis Aquat Organ 2001;47:73-9.

[33] Kitamura S, Jung S, Suzuki S. Seasonal change of infective state of marine birnavirus in Japanese pearl oyster Pinctada fucata. Arch Virol 2000;145:2003-14.

[34] Lesser MP, Kruse VA. Seasonal temperature compensation in the horse mussel, Modiolus modiolus: metabolic enzymes, oxidative stress and heat shock proteins. Comp Biochem Physiol A Mol Integr Physiol 2004;137:495-504.

[35] Huchette S, Clavier J. Status of the ormer (Haliotis tuberculata) industry in Europe. Journal of Shellfish Research 2004;23:951-5.

[36] Travers MA, Basuyaux O, Le Goic N, Huchette S, Nicolas JL, Koken M, et al. Influence of temperature and spawning effort on Haliotis tuberculata mortalities caused by Vibrio Harveyi: an example of emerging vibriosis linked to global warming. Global Change Biology 2008;doi:10/1111/j.1365-2486.2008.01764.x.

[37] Perdue J, Beattie J, Chew K. Some relationships between gametogenetic cycle and summer mortality phenomenon in the Pacific oyster, C. gigas in Washington State. Journal of Shellfish Research 1981;1:9-16.

[38] Nicolas JL, Basuyaux O, Mazurie J, Thebault A. Vibrio carchariae, a pathogen of the abalone Haliotis tuberculata. Dis Aquat Organ 2002;50:35-43.

[39] Ngo TTT, Choi K. Seasonal changes of Perkinsus and Cercaria infections in the Manila clam Ruditapes philippinarum from Jeju, Korea. Aquaculture 2004;239:57-68.

\section{Figure captions}

Figure 1 - Expression of $28 S$ rDNA as measured in Q-PCR from samples monthly collected from August 05 to July 08 . Values were inferred from 4 replicates measured in duplicate \pm SEM (bar). See the text for statistical analysis. Note the lowest expression Aug 05-Jan 06 and the highest expressions Jun 06-Mar 07, then Sep 07-Jul 08.

Figure 2 - Salinity and temperature of seawater, and E. coli tissue content of mussels. Expression of HSP70, defensin, mytilin B, myticin B and lysozyme as measured in Q-PCR from samples monthly collected from August 05 to July 08. Values were inferred from 4 replicates measured in duplicate \pm SEM (bar). See the text for some statistical analysis. Note the 4 lowest salinities corresponding to heavy rainfalls in Sep 05, Sep-Dec 06, May 07 and Jun 08, and the 4 peaks of E. coli tissue content in Sep 05, Feb 06, Nov 06 and Jun 08. Note the existence of some modulations of gene expressions, not identical between the five genes, and the global lower expressions during winters 06 and 07. 
Figure 3 - Representation of variables on the main plan by correlation circles related to defensin (A) and to lysozyme (B). Note the negative correlations on axe 1 between salinity (SAL) and $E$. coli tissue content (ECOLI) in both cases. Note also the positive correlations on axe 2 between defensin (DEF) and temperature (TEMP)(A) and between lysozyme (LYS) and temperature (B).

\section{Figure 1}




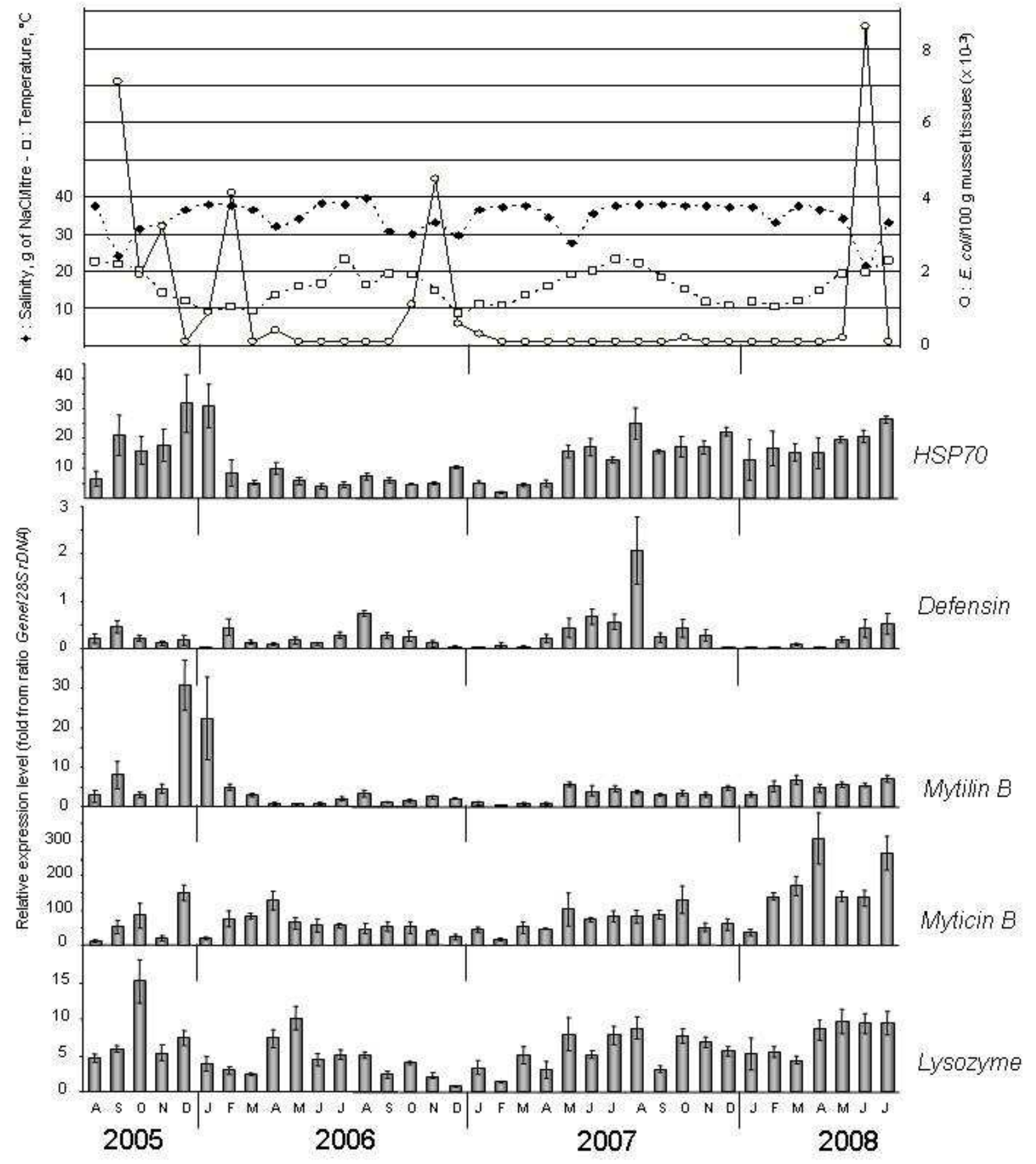

Figure 2 
452 Figure 3

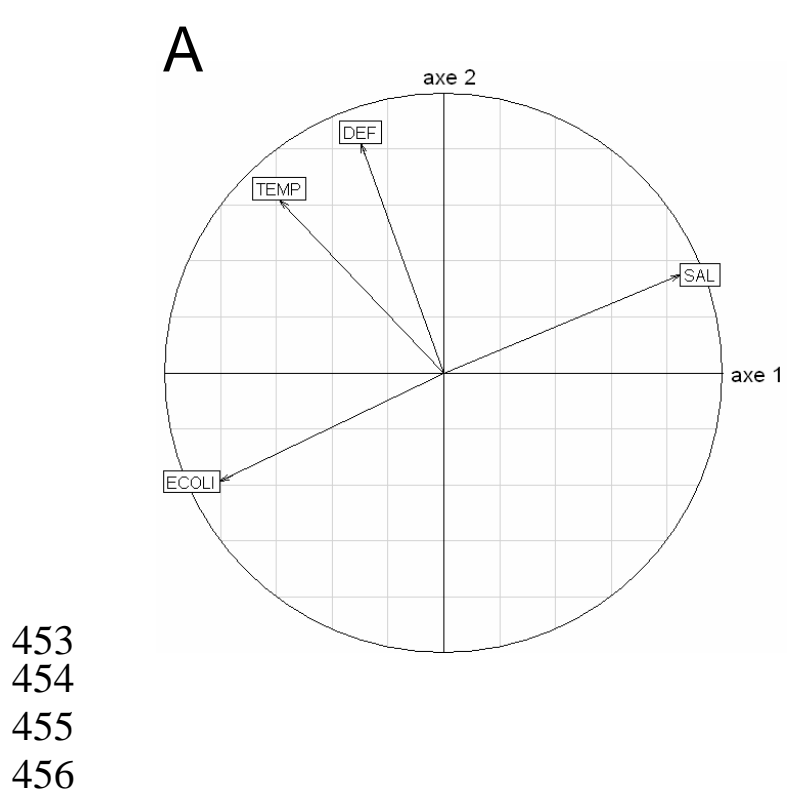

456

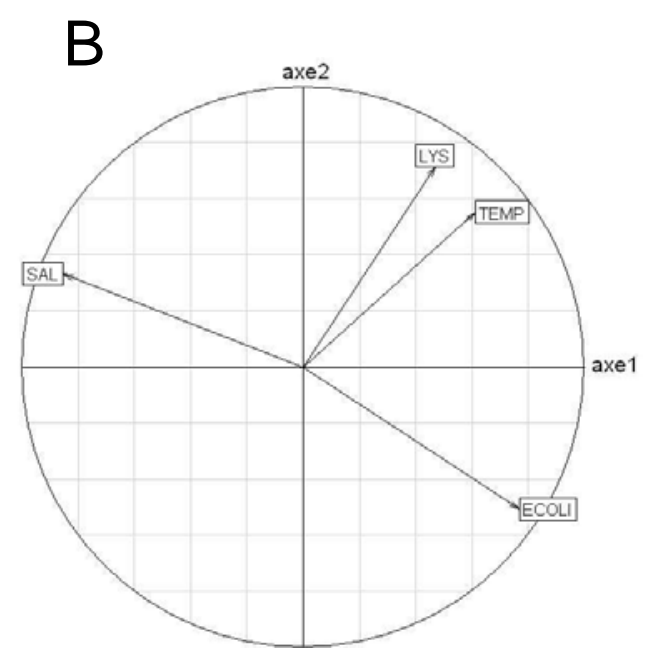

